Chickens, Partridges, and the /tor/ of ancient Israel and the Hebrew Bible

Altmann, Peter ; Spiciarich, Abra

DOI: https://doi.org/10.13109/wdor.2020.50.1.2

Posted at the Zurich Open Repository and Archive, University of Zurich ZORA URL: https://doi.org/10.5167/uzh-188236

Journal Article

Originally published at:

Altmann, Peter; Spiciarich, Abra (2020). Chickens, Partridges, and the /tor/ of ancient Israel and the Hebrew Bible. Die Welt des Orients, 50(1):2-30.

DOI: https://doi.org/10.13109/wdor.2020.50.1.2 


\title{
Chickens, Partridges, and the /tor/ of Ancient Israel and the Hebrew Bible
}

\author{
Peter Altmann and Abra Spiciarich
}

\begin{abstract}
Traditionally translated as "turtledove," several scholars have recently argued for alternative renderings for the term /tor/ in the sacrificial ordinances of Gen 15:9; Num 6:10; and frequently in Leviticus. The importance of the identification of /tor/ lies in its impact on our understanding of biblical sacrificial practices, anthropological understandings of Israelite cult, and their relationship to Israelite meal practices. Specifically, hinging on the nature of the /tor/ is the question of whether all sacrificial animals were domesticated, and to what degree, which has ramifications for the understanding of the connection between the boundaries of Israelite household and Israelite altar. In a first step, this paper will incorporate data concerning the identification of archaeological remains of birds throughout the Southern Levant, allowing material culture to weigh in on the discussion. A second step will bring together the zooarcheological data and biblical reflections on possible identifications for this bird in ancient Israel.
\end{abstract}

What is the significance of the particular animals chosen for sacrifice? Modern Hebrew Bible scholarship, especially on the Priestly sacrificial prescriptions in Leviticus (e.g., Lev 1-7), relates these animals designated for sacrifice - cattle, sheep, goats, and certain birds - to the Israelite table and the tables of the nations, viewing them on a continuum symbolizing proximity to the divine. One prominent example of this conception appears in Jacob Milgrom's landmark Leviticus commentary (Milgrom 1991), which formulates the symbolic relationship of proximity to God and meat consumption as follows:

$\begin{array}{lll}\text { Specific domesticated } & & \\ \text { Animals as sacrifices } & - & \text { Priests } \\ \text { Clean animals } & - & \text { Israelites } \\ \text { All edible animals } & - & \text { All humans }\end{array}$

The three divisions of humanity are correlated to three animal divisions: all animals are permitted to humankind (Gen 9:3-5); Israel may eat those pronounced clean (Lev 11); and of the clean, the domesticated and unblemished qualify as sacrifices to the Lord and are partially consumed by the priests and their families (Lev 22:17-25; Milgrom 1991:722 with graphic; also Hendel 2007).

Milgrom argues that the development toward sacrifice of solely domestic animals represents a: 
“... conscious effort to restrict the sacrificial quadrupeds to a narrower range of edible animals, namely, the domestic species, as a model for the differentiation between priests and Israelites" (1991:720).

He maintains that the purpose for this distinction lays in this analogy between consumption habits and holiness - that is, acceptable proximity to the deity. In the same way that sacrificial animals represent a subcategory of those allowed for Israelite consumption, a distinction is also made between clean and unclean (tame'), or abominable (šeqeș) animals. This distinction provides an analogy to the separation between Israel, corresponding to clean animals for consumption, and the rest of humanity, equated with all animals, but not their blood because of the prohibition in Gen 9.

In this citation Milgrom speaks of the domestic quadrupeds; and while his view may hold true for those several sacrificial species, biblical scholarship largely assumes that the same logic holds true for the sacrificial fowl, unfortunately with little evaluation of the merits of this same analogy for the birds. Because Milgrom and most scholarship assumes that the section in Lev 11 on the birds (vv. 13-19) comes from the same compositional layer as vv. 2b-8 (on the large quadrupeds), he appears to expect the same conception to carry through: only domesticated fowl would be available for sacrifice. Milgrom elsewhere (1990: 178-80) makes this assumption more explicit, asserting that the "domesticated" and "unblemished" belong to the Lord as sacrifices, citing Lev 22:17-25 in support. The problem with this assertion is that it omits reference to birds, not to mention that Lev 22 is usually attributed to a later (typically Holiness) compositional layer.

Walter Houston's thorough monograph on the biblical dietary prohibitions concurs with Milgrom on this point:

"I think we can reasonably assume that doves were kept as domestic birds, especially since otherwise they would be the only wild victim permitted in the sacrificial codes of Ugarit and Leviticus ... (1993: 188)"

While the accuracy of this statement for Ugarit is disputable, more central to the discussion here is the straightforward logical presupposition undergirding the argument about the necessary relationship between the table and the altar, or rather the domicile and the altar. Because people supposedly raised all other sacrificial items in Ugarit and the cultures behind the biblical texts (i. e., Israel and Judah) as domesticated animals, this must have been the case for the birds as well.

Borowski (2002: 412) similarly surmises:

"The large quantity of birds that must have been required for sacrifices suggest that the Israelites were not relying on captured birds, but that the major- 
ity were probably raised under controlled conditions. However, no columbaria or other installations related to bird-keeping earlier than the Hellenistic period have been discovered in Palestine."

Even though Borowski cannot point to any evidence from pre-Hellenistic periods, he assumes (1) that these birds must have been raised rather than caught, and (2) that these birds consist of dove and pigeon or turtledove varieties. His statement follows the traditional identification of the two terms, tor and bene yonah, in Lev 1:14 and elsewhere (e. g., Lev 5:7, 11; 12:6, 8; 14:22, 30; 15:14; 29; Num 6:10), as forms of domesticated turtledoves and rock doves/pigeons. Such an understanding follows naturally from the LXX, which in Lev 1:14 reads:

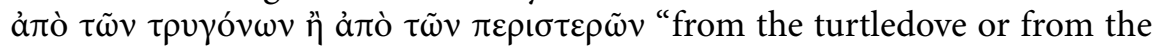
rock dove/pigeon."

In his recent commentary on Lev 1-10, however, James Watts deviates from the traditional rendering for the first term, translating Lev 1:14, for example, as:

“... chicken or any kind of pigeon (2013: 218)."

While the change from turtledove to chicken is significant and will be addressed below, the logic remains constant. Watts states:

"Since P permits only domestic animals on the altar, [Lev] 1:14 makes the best sense if it refers to the two major categories of domesticated food birds in the ancient Near East, chickens and pigeons (2013: 219-220)."

Watts notes, therefore, that turtledoves may not provide the best representative of a domestic fowl, given that there is no substantial evidence for their domestication in the ancient Near East. He develops his proposal in close dialogue with Staubli (2008), which challenges the traditional consensus. However, Staubli concludes, and this investigation will affirm, that the best candidate for the tor is found in indigenous wild fowl. Staubli wisely builds his argument on the basis of comparative Semitic philology and on a survey of the animals in the southern Levant.

The investigation below will cover some of the same ground, adding:

1. further observations on broader ancient Near Eastern practices,

2. and a zooarchaeological survey of the bird remains in the southern Levant from the Iron Ages through the Hellenistic periods.

We intend to show that, assuming the sacrificial ordinances of Leviticus concerning the offering of fowl date prior to the Hellenistic period, then these ordinances have the sacrifice of captured wild birds in view. Through this investigation, the most likely species - if the category should be understood as a 
species - is the chukar partridge (Alectoris chukar). If the results of this study are accepted, then it calls for a revision of the relationship between the sacrificial altar and the Israelite table, questioning the symbolic connections promoted by Milgrom above.

\section{Definition of Domestication}

In order to argue that the biblical texts prescribe the sacrifice of wild rather than domesticated birds, it is necessary to provide some definition of the term "domesticated." While such definitions are difficult, several indicators of domestication often take on significance in the process of an animal's domestication (Driscoll et al. 2009: 9972):

1. Tolerance of proximity to humans, in the sense that the animal will not flee proximity to humans if given the opportunity,

2. Change in reproductive cycle,

3. Adaptation of diet,

4. Changes or accentuations of specific physiological features,

5. Behavioral changes.

Of these changes, very few of them appear in the current available material, iconographic, or textual sources for fowl in the ancient Near East. Criteria 2 and 3 play little role at all in available sources. Changes in the physiological features of cattle, sheep, goats, and horses set these animals off from their wild counterparts, and likewise for geese (see below). However, this is not the case for rock doves/pigeons or turtledoves. Likewise, one might suggest increased docility of the herd and flock animals. Among the fowl of the ancient Near East, a similar conclusion may be drawn for geese. Perhaps a further characteristic, the introduction of a foreign species could provide some evidence for domestication, which would be the case for chicken.

\section{Possible Domesticated Fowl in the Ancient Near East and their Appearance in the Hebrew Bible}

This section will survey the most frequently consumed fowl in the ancient Near East, noting the evidence for domestication and their importance in various contexts. In short, it shows that there is clear evidence for several categories of fowl fitting into the domesticated category in the ancient Near East prior to the Hellenistic period; however, there is only minimal evidence for rock doves/ pigeons or turtledoves. 


\section{A. Geese and Ducks}

The strongest evidence for domestication among fowl appears for ducks and geese, specifically the graylag goose and white-fronted goose in Egypt (Brewer 2002: 453). Support comes by way an $18^{\text {th }}$ Dynasty depiction of graylag geese, including a gosling with light feathers rather than the coloring of the wild geese (Osten-Sacken 2015: 242). This detail indicates a marked physiological change, keeping with Criterion 4 of domestication above.

Another stream of evidence arises from temple administrative records from Mesopotamia, which attest to the hiring of geese-herders to raise geese in the same way that shepherds raised sheep (Osten-Sacken 2015: 453). This practice indicates the geese's tolerance of human proximity. By contrast, many other birds were kept, especially in Egypt, but they were caught and fattened rather than bred and raised. Surprisingly, geese hardly appear, if at all, in the Hebrew Bible: the only possibility is in 1 Kgs 5:3 [ET: 4:23].

\section{B. Turtledoves}

In Mesopotamia the turtledove, Akkadian sukanninu, frequently ends up on the table as well as in the sanctuary (Salonen 1973: 251). In fact, ten thousand of them appear on the table in Ashurnasipal's Calah banquet. However, as $C A D$ posits, they were caught and then fattened, suggesting instead that they remained undomesticated:

"The suggestion 'turtledove' is based on the onomatopoeic Sum. name tukur; possibly the sukanninu is a wild dove, as it is caught by the fowler; it can also be kept and fattened ... among domestic fowl (ducks and geese), albeit in much smaller numbers" (CAD S: 354).

In fact, these "much smaller numbers" may provide the decisive evidence in suggesting that they were caught rather than domesticated. When the evidence is compared with Egypt, it is likely that most birds outside of the geese and ducks in Mesopotamia were caught in the wild and then kept for a time to fatten them up before consumption, rather than breeding them in a domestic setting and developing them into domesticates (Brewer 2002: 453-54; Osten-Sacken 2015: 201).

\section{Domestic Chickens}

Chicken (Gallus gallus) was domesticated in Southeastern Asia (Benecke 1994) prior to their introduction to the southern Levant in the Middle Bronze Age (Hellwing et al. 1993). Therefore, the appearance of chicken in the Levant, out- 
side of its original habitat, suggests human involvement and domestication as well. However, as we will discuss below, their remains only become dominant in the territories of Israel/Judah in the Hellenistic period, and their primary usage before this period remains uncertain. Traditionally their significance in the ancient Near East has been linked to the significance of the sun and moon, especially with the deity Nusku, Mesopotamian god of light (Eggler forthcoming).

There is little question that the southern Levantine communities were familiar with the chicken and rooster of Gallus gallus. In terms of iconography, the rooster appears in ancient Near Eastern iconography in Mesopotamia on a $14^{\text {th }}$ century BCE Assyrian ivory and in Egypt on an ostracon from Thebes from the $13^{\text {th }}$ century. In the southern Levant the rooster is found on a $12^{\text {th }}-9^{\text {th }}$ century BCE seal from el-Jib (Gibeon; see Eggler forthcoming). The clearest support comes in the form of the seal of Ya'azanyahu from Tell en-Nesbah (often dated to $600 \mathrm{BCE}$ ), which contains the depiction of a rooster (Eggler forthcoming; Avigad and Sass 1997, 52; Badè 1933: 150-56), usually understood as "fighting cocks" (Sass 1993: 220). This era - the sixth-fifth century exilic and postexilic period - is the high point for iconographic depictions of roosters in the Ancient Near East (Eggler forthcoming).

There is no clear mention of chicken in the biblical text. There is the questionable translation of zarzîr (Prov 30:31) as "rooster" in some translations, though it is rendered in others as "greyhound." "Rooster" follows the LXX translation, à $\lambda \dot{\varepsilon} \kappa \tau \omega \rho$, but the comparative Semitic evidence points in different directions: Syriac zazī/ūrā and Arabic zurzūr both mean starling, while Arabic zirzirru means migratory locust.

Similarly suspect is the translation of śekwî̀ (Job 38:36) as "rooster," for which

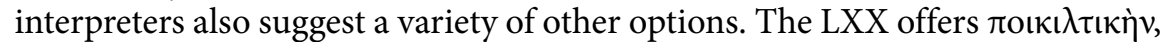
a neologism also found in Exod 37:21 meaning "embroidered" (Habel 1985: 523). Even more questionable is the proposal that tukkiyyim in $1 \mathrm{Kgs} \mathrm{10:22/2} \mathrm{Chr} \mathrm{9:21}$ means "chicken," for again, other renderings (in this case "peacock" or "ape") are more likely (HALOT: 1731). However, the term is absent from the LXX, so it may represent a Hellenistic period addition.

As mentioned above, Watts has proposed translating tor as "chicken." On first comparison with the broader ancient Near Eastern iconographic data, chicken does not play a significance role as a sacrificial bird or as a provider of meat for consumption. The main connections instead appear to be in connection with light - thus perhaps as waking with the dawn - or as a fighting bird.

\section{Doves and Pigeons}

It is more difficult to apprehend the status of the rock dove/pigeon (Columba livia) with regard to domestication because of the lack of distinguishing features in the faunal remains between the domestic and wild birds. 
However, when considering the question of domestication, while rock doves and domestic pigeons - which are the same species of Columba livia - appear in the archaeological record, one cannot distinguish between the wild and the domestic varieties on the basis of the bones examined thus far (Croft 2004: 2308). Neither archaeology nor the study of iconography have identified any structures where people kept the birds in the Levant prior to the Hellenistic period columbaria, such as those from Hellenistic Maresha and Ramat Rahel, except for an Iron II dovecote from Amman, Jordan (Kakish 2012).

General claims are often made for much earlier domestication of pigeons, looking for support to the flood narrative in Gen 8:8-12 in comparison with the earlier Mesopotamian flood narratives (Keel and Winter 1997: 80-81). The focus in the Mesopotamia story lies much more on the raven than on the dove, however, which appears to have been a West Semitic adaptation brought about by the non-Priestly source. In any case, even though the homing abilities of pigeons are extremely well documented and appropriated throughout modern history, it may be that the help provided by these birds in ancient Israel, Egypt, and Phoenicia related more to their migratory patterns, to which Wenamun ( $11^{\text {th }}$ century BCE) refers: "Do you not see the migrant birds going down to Egypt a second time?" (Lichtheim 1997: 92).

In conclusion, when set in the context of the comparative evidence from Egypt and Mesopotamia, there is little evidence that rock doves/pigeons or turtledoves - as domesticated species - appeared on the sacrificial altars in ancient Israel and Judah or in the texts. In fact, the most widely attested domesticated fowl from the pre-Hellenistic periods - geese and ducks - do not figure in the biblical offering texts. Furthermore there is no tie between chicken and the altar; they are instead connected to light and entertainment as fighters. This evidence in itself loosens the connection between the biblical domicile and the Yahwistic altar.

\section{Zooarchaeological Remains of Birds}

A further source of evidence for the appearances and uses of fowl arises from the zooarchaeological remains of birds. Biblical scholars have made little use of this evidence to date, in part because of its relative non-accessibility for biblical studies. In order to remedy this gap, the following section will provide a brief introduction to zooarchaeology, followed by an analysis of avian remains from southern Levant, from relevant assemblages dating from the Iron Ages through Hellenistic period.

Zooarchaeology is the study of how humans and animals functioned at different times and at different levels to provide sustenance, to create commodities, and to serve as ideological symbols - based on remains found in archaeological contexts (deFrance 2009; Russell 2011; Twiss 2012). Economic and 
symbolic motives of animal use change and develop over time as a response to social changes and environmental conditions. Comprehending socioeconomic patterns through zooarchaeological methodologies is based on differential access to meat, distribution mechanisms, trade, and literary sources (deFrance 2009).

The presence of birds in archaeofaunal assemblages has been consistently overlooked, as their frequency is generally lower than domesticated livestock (i. e., sheep, goat, cattle, and donkey). Avian remains are susceptible to taphonomic processes, which are the affects of decomposition and burial. Lower bone density of avian remains causes them to decay and fracture, limiting their presence in archaeological assemblages. Additionally, the small size of avian remains causes them to be easily missed in hand-picked assemblages. However, remains of birds have been identified at many sites throughout the southern Levant, in all periods from the prehistoric periods to the later historical periods, allowing for an in-depth diachronic investigation to be carried out.

\section{A. Methodology}

Data for the current survey was collected by reviewing 40 zooarchaeological assemblages from 21 sites throughout the Levant in published and unpublished reports (see Appendix I). Collected data includes the "Number of Identified Specimens" (NISP), the relative frequency of each avian species (NISP\%), and collection method of the excavation. This survey did not separate avian remains into sub-periods (e.g., Late Bronze III, Iron Age IIA, etc.) to allow for the avian NISP of each period to be statistically viable (>250). An exception to the division of sub-periods is a tangential survey of avian remains from Jerusalem, given the cultic importance of the site.

The investigation below focuses on relevant avian species, namely those that are native to the ecological niches of the southern Levant. Both domestic and wild avian species are found regularly in archaefaunal collections. The most common avian species identified in the Levant are chukar partridge (Alectoris chukar), rock dove/pigeon (Columba livia), graylag geese (Anser anser), mallard ducks (Anas platyehynchos), and domestic chicken (Gallus gallus). Further common wild avian species are individual to a site's immediate geographical region (e.g., coastal, inland, desert, marsh, etc.).

The following survey presents the results and trends observed by analyzing specific geographical regions and species diachronically. Certain biases can emerge from this type of analysis. First, not dividing the assemblages into short chronological phases results in broad trends for larger periods of time. Second, such an exploration may overlook differences between livestock exploitation and taphonomic history of a site. Thirdly, comparing faunal reports by various authors raises numerous problems, from preservation variation, inter-versus 
intra-site variability, as well as discrepancies between analytical methods. Nonetheless, this division of collected avian data is indispensable in any attempt to reconstruct exploitation processes of the past.

In order to construct an effective database, reports included in the current study have to:

1. enable the attribution of the raw data to one of the periods referred to above, and

2. identify birds down to genus. Avian remains only identified to body class (i. e., large, medium, or small aves) or unidentified were omitted.

\section{B. Results}

\section{i. Birds in the Iron Age I}

Wild and exotic birds are the most common in the Iron I, representing nearly half of all birds during the period, with $47 \%$ (Figure 1, Appendix 2). While wild and exotic birds are exploited at most sites, they are primarily utilized along the coastal plain sites of Tel Dor and Tel Yoqne'am. Geese are the second most common avian species in the Iron I, with $16 \%$. Geese were utilized throughout the Levant for their meat, fat, and feathers (Houlihan 2001: 189-91). In the previous Late Bronze Age, geese were associated with the elite, and their consumption was linked to Egyptian emulation (Koch 2014). Chicken was not widely consumed with only $6 \%$, and it was only identified at Tel Dor and at Shiloh (Figure 1, Appendix 2). Rock doves/pigeons are found throughout the region but in low numbers. Partridges are also meagerly present representing only $2 \%$; when present they are primarily exploited in the Hill Country and the Shephelah regions.

\section{ii. Birds in the Iron II}

Partridge gains popularity in the Iron II, representing $34 \%$ of birds in the period (Figure 2, Appendix 2). The majority of the partridge remains derive from the Hill Country and Shephelah. However, partridge was identified at almost every site during the Iron II, with the exceptions of Beit Hakerem, a farmhouse near Jerusalem, and Bab-el-Hawa in Syria. Avian remains at Beit Hakerem and Bab-el-Hawa included only chicken. Chicken, though not heavily exploited, was the fourth most popular avian species representing $15 \%$, and was identified at almost every site in the period (Figure 2, Appendix 2). Notably, the frequency of chicken in the Iron Age II is greater than the period prior. Geese, similar to the previous periods, are the second most prevalent avian species identified in the Iron II with $23 \%$. Geese remains also appeared only in sites with prior evidence of geese. Exploitation of rock doves/pigeons (Columba livia, not turtledoves) in the Iron II is widespread but in limited numbers. Rock doves/pigeons represent $11 \%$ of Iron II birds and are present throughout the region (Figure 2, Appendix 2). 
Jerusalem is unique in the Iron II in that there are six faunal assemblages from different areas of the site, allowing for an inter-site comparison of the avian remains. Comparing the bird frequencies of different areas within Jerusalem illustrates socioeconomic patterns in the utilization of different avian species (Figure 3, Appendix 2). The Ophel is a site known to be of higher socioeconomic position, based on its animal economy, as well as its proximity to the Temple (Horwitz and Tchernov 1989). The distribution of avian species in the Ophel reinforces the elite nature of the area. Jerusalem's Ophel has the greatest diversity of species with geese, partridge, rock dove/pigeon, chicken, duck, as well as evidence of turtledove. The monumental stepped stone structure (Area G), which is closer to the Ophel, only has evidence of partridge, rock doves/pigeons, and geese (Tamar and Bar-Oz 2015).

Comparatively, birds identified in the residential areas of Jerusalem, along the southeastern ridge of the Kidron Valley, are primarily chicken and partridge, some geese, and little rock dove/pigeon (Horwitz 1996). The main difference between the various areas of Jerusalem is the greater degree of chicken in the residential areas, suggesting chicken was primarily used within the domicile. The frequency of rock doves/pigeons and partridges is similar throughout Jerusalem, with rock dove/pigeon representing $\sim 10 \%$ and partridges representing $30 \%$ in each area. Viewing rock doves/pigeons and partridges together as gamebirds, they emerge as Jerusalem preferred type of bird.

\section{iii. Birds in the Persian Period}

Avian remains in the Persian period (only 160 total) are scarce due to the lack of faunal reports dating to this period. The view from the current data suggests that a major change was taking place in the avian exploitation of the southern Levant. Chicken is starting to become the most frequent avian species with $36 \%$, and is widely consumed throughout the region (Figure 4, Appendix 1). The exception to this pattern is the remains from the Stepped Stone Structure fills in Jerusalem. The birds present in Jerusalem are similar to the prior Iron II, with primarily partridge and rock dove/pigeon, as well as a little goose and chicken (Tamar and Bar-Oz 2015). Comparing the remains from Jerusalem to Horvat Zimri (Horwitz 1993), a small fortress in Jerusalem's hinterland, clearly demonstrates the difference in cultic exploitation versus domiciliary exploitation of birds. The cultic capital is primarily exploiting partridge and rock dove/ pigeon, and the fortress was consuming domesticated chicken.

\section{iv. Birds in the Hellenistic Period}

The overarching avian trend in the Hellenistic period is the growing prevalence of chicken throughout the region. Chicken represents $93 \%$ of birds present, and a majority of sites only have remains of chicken (Figure 5, Appendix 1). One 
outlier may be the birds at Khirbet Qeiyafa, which were identified as galliformes (i. e., fowl), possibly as Chukar partridge (Alectoris chukar) (Kehati 2009). The ambiguity of a positive identification limits any conclusions for explaining why Khirbet Qeiyafa was not exploiting chicken in a similar manner to the rest of the region. Published avian remains from Jerusalem primarily derive only from domestic contexts, expounding why there is only evidence and a dominance of chicken and geese (Table 4, Appendix 1. Figure 4, Appendix 2).

Thus, the overall trend away from a variety of birds in the faunal record to an overwhelming predominance of chickens is complete by the Hellenistic period. The popularity of chicken is striking when taking into account the architectural remains of columbarium that housed rock dove/pigeons, in order to produce fertilizer, throughout the southern Levant during the Hellenistic period. However, there is a lack of avian remains from cultic contexts, especially from Jerusalem, limiting our perspective for the cultic use of birds during the Hellenistic period.

\section{v. Birds in Jerusalem: A Diachronic Investigation}

Animal remains from Jerusalem, a central cultic site specified in the biblical texts, are key as juxtaposing evidence for understanding the sacrificial practices elucidated in the texts. Animal remains have been reported from every period of the first millennium, allowing for diachronic survey to be carried out (Figure 6).

There is an increased dominance of partridge throughout the Iron Ages, with a clear peak in the Iron IIC ( $7^{\text {th }}$ century BCE), which also parallels the demographic and cultic rise in Jerusalem. Jerusalem during the Persian period is enigmatic; however, it is generally accepted that the size and population of the city was meager compared to the previous Iron Ages and subsequent Hellenistic and Roman periods due to the destruction of the city in 586/7 BCE and its return to prominence only in the Hellenistic period (Lipschits 2011; Finkelstein et al. 2011; Geva 2014). Continued exploitation of partridge and rock dove/ pigeon in the Persian period suggests that these species were locally captured and consumed during this period, and they also continued serving as sacrifices in the rebuilt temple. On the other hand, chicken is used elsewhere primarily for sustenance and possibly as entertainment (i. e., cockfighting).

The popularization of chicken during the Hellenistic period can also be seen from domicile dwellings along the southeastern ridge of the Kidron Valley at this time. The Early Roman period saw another cultic peak in Jerusalem. Jerusalem's Early Roman landfill, located on the slopes of the Kidron Valley, has evidence of refuse disposal based on socioeconomic and cultic process. The areas of the landfill closer to the Temple have been shown to represent more cultic refuse than the landfill closer to the domestic downtown of the southeastern ridge (Bar-Oz et al. 2007; Spiciarich et al. 2017). This distinction is based on 
the absence of pigeon in the residential faunal assemblage versus their presence in the refuse closer to the Temple. Chicken is dominant everywhere in Jerusalem during the Early Roman period. Their prominence relates to the demographic rise during the first centuries and to a need for a quickly maturating meat source, which chicken fulfilled.

There are two important conclusions to be drawn from the above discussion. First, there is a strong change in the presence of species throughout the southern Levant from a variety of birds, though especially partridges and geese, to chicken. However, there is primarily one location that contradicts this trend at least through the Persian period - those sites closest to the Jerusalem temple. These locations attest to the conservative retention of partridge (and in the Persian period rock doves/pigeons). Second, the lack of turtledove throughout should also be noted from the discussion of Jerusalem's avian remains. As a whole, the zooarchaeological evidence opposes the hypotheses of tor either as turtledove or as chicken on the altar of the First or Second Temples in Jerusalem to the degree that the fowl appearing in the biblical texts accord with the fowl on the Jerusalem altar.

\section{Tor as Wild Partridge}

Given the absence of turtledove and chicken in close proximity to Jerusalem's temple, the primary arguments to date for a wild type of bird offering including partridges comes from Staubli 2008. He proposes that the term tor began as the term for a bird from the family phasianidae in the early layers of the Hebrew Bible and the time period of the Israelite/Judahite cult contained therein (2008: 355-59).

In addition to the zooarchaeological evidence presented above for the absence of turtledove, Staubli provides a further argument against rendering tor as turtledove (Streptopelia turtur): why would the Hebrew Bible name two kinds of birds of the same family (Columba), when both the rock dove/pigeon and turtledove might be subsumed under the term bene yonah בני ינה/יונה (2008:362)?

The possibility of tor as chicken suggested by Watts is also problematic because the zooarchaeological investigation presented above demonstrated that chickens were not widespread before the Persian period. Furthermore, they were hardly close to the Temple precincts until the Hellenistic period. In any case, perhaps domestic chickens may have been included along with other birds as tor. However, Watts's hypothesis does not account for the iconographic data from the Iron Age, or rather the pre-Hellenistic periods, with regard to the place of this animal in the thought world of ancient Israel: its place was as a symbol of light, a fighting bird, and domestic food rather than connected to the altar. This, in itself, presents a challenge for many interpretations of the symbolism inherent in the choice of sacrificial animals. 
The best option for the tor is the members of the family of Phasianidae, specifically Chukar partridges, but also possibly including the off chicken.

This conclusion may also provide an explanation for why the LXX changes the term to turtledove: partridges, especially the Chukar partridge (Alectoris chukar), are not found in Egypt. This bird only spread as far as the Sinai Peninsula, so Houlihan does not even include it in his expansive study of the birds of ancient Egyptian iconography. On the flip side, the turtledove appears in Egyptian art quite frequently (1986: 103-6).

\section{Conclusion}

In sum, this discussion of the cultic use of birds has shown that the relationship between the wild fowl versus the raising of domestic fowl and the sacrificial altar are considerably more ambiguous than often proposed. The evidence in favor of this situation arises from a number of perspectives:

1. Non-domestic fowl, especially partridges, are extremely common in close proximity to the temple mount in Jerusalem.

2. Given the lack of chicken in this location and the predominance of partridge in the Iron Ages, it is likely that the tor designates a Chukar partridge or some combination of Phasianidae family fowl; and

3. The likelihood that even many or all doves/pigeons may have been caught in the wild and kept until slaughter, rather than raised domestically at all periods of the southern Levant until the Hellenistic period.

Therefore, biblical scholars should include caught animals as part of the animals that could function as offerings in the Priestly and other texts on the basis of this first line of evidence. This inclusion calls for a significant adjustment of the relationship between the Israelite table and the table of their God.

\section{References}

Aboelsoud, N.H. 2010. Herbal Medicine in Ancient Egypt. Journal of Medicinal Plants Research 4, 82-86.

Aharoni, I. 1938. On Some Animals Mentioned in the Bible. Osiris (5), 461-78.

Albarella, U. 2005. Alternate Fortunes? The Role of Domestic Ducks and Geese from Roman to Medieval Times in Britain. Feathers, Grit and Symbolism. In: Grupe, G., and Peters, J., (eds.) Birds and Humans in the Ancient Old and New Worlds (Documenta Archaeobiologiae 3). Rahden: Leidorf, 249-58.

Avigad, N., and Sass, B. 1997. Corpus of West Semitic Stamp Seals. Jerusalem: The Institute of Archaeology, The Hebrew University of Jerusalem.

Barnett, R.D. 1982. Ancient Ivories in the Middle East and Adjacent Countries (Qedem 14) Jerusalem: Hebrew University.

Benecke, N. 1994. Der Mensch und seine Haustiere: die Geschichte einer jahr-tausendealten Beziehung. Stuttgart: Theiss. 
Ben-Shlomo, D. 2005. Material Culture. In: Dothan, M., and Ben-Shlomo, D., (eds.) Ashdod VI: Excavations of Areas $H$ and $K$, the Fourth and Fifth Seasons of Excavations. Jerusalem: IAA Report Series, 63-246.

Blasco, R., Finlayson, C., Rosell, J., Marco, A.S., Finlayson, S., Finlayson, G., Negro, J.J., Pacheco, F.G. and Vidal, J.R. 2014. The Earliest Pigeon Fanciers. Scientific Reports, 4: 5971, 1-7.

Blasco, R., Rosell, J., Rufà, A., Marco, A. S., and Finlayson, C. 2016: Pigeons and Choughs, a Usual Resource for the Neanderthals in Gibraltar. Quaternary International 421, 62-77.

Boessneck, J. 1986. Vogelknochenfunde aus dem alten Ägypten. Annalen des Naturhistorischen Museums in Wien 88/89, 323-44.

Boessneck, J. 1988. Die Tierwelt des Alten Ägypten: untersucht anhand kultur-geschichtlicher und zoologischer Quellen. Munich: Beck.

Boessneck, J. 1995. Birds, Reptiles and Amphibians. In: LaBianca, Ø.S. and von den Driesch, A., (eds.) Faunal Remains: Taphonomical and Zooarchaeological Studies of the Animal Remains from Tell Hesban and Vicinity (Hesban 13). Berrien Springs, MI, 131-68.

Boessneck, J. and von den Driesch, A. 1992. Tell el-Dab'a VII: Tiere und Historische Umwelt im Nordost-Delta im 2. Jahrtausend v. Chr. anhand der Knochenfunde der Ausgrabungen 1975-1986. (Österreichische Akademie der Wissenschaften Denkschriften der Gesamtakademie 11) Vienna: Österreichischen Akademie der Wissenschaften.

Borowski, O. 2020, “Animals in the Religions of Syria-Palestine.” In: Collins, B.J., (ed.) A History of the Animal World in the Ancient Near East (HdO 64) Leiden: Brill, 405-24.

Brewer, D. 2002. Hunting, Animal Husbandry and Diet in Ancient Egypt. In: Collins, B.J., (ed.) $A$ History of the Animal World in the Ancient Near East (HdO 64) Leiden: Brill, 427-56.

Caubet, A. 2002. Animals in Syro-Palestinian Art. In: Collins, B.J., (ed.) A History of the Animal World in the Ancient Near East (HdO 64) Leiden: Brill, 211-34.

Clements, J.F. 2011. The Clements Checklist of Birds of the World. Ithaca: Cornell University Press.

Clements, J.F., Schulenberg, T.S., Iliff, M.J., Roberson, D., Fredericks, T.A., Sullivan, B.L., and Wood, C.L. 2014. The eBird/Clements Checklist of Birds of the World: Version 6.9. Downloaded from http://www.birds.cornell.edu/clementschecklist/ download/.

Croft, P. 2004. Archaeozoological Studies: Section A. In: Ussishkin, D., (ed.) The Renewed Archaeological Excavations at Lachish (1973-1994) (Tel Aviv University Monograph Series) Tel Aviv: Institute of Archaeology, 2254-2453

Darwin, C. 1859. On the Origin of Species by Means of Natural Selection. London: Murray.

deFrance, S.D. 2009. Zooarchaeology in Complex Societies: Political Economy, Status, and Ideology. Journal of Archaeological Research 17, 105-68.

Deng, H., Yuan, J., Song, G., Wang, C., and Eda, M. 2013. The Reexamination of the Domestic Chicken in Ancient China. Chinese Archaeology 6, 83-96.

Dietler, M. 2007. Culinary Encounters: Food, Identity and Colonialism. In: Twiss, K. C. (ed.), The Archaeology of Food and Identity, Occasional Paper No. 34, Center for Archaeological Investigations, Southern Illinois University, Carbondale, 218-42.

von den Driesch, A. and Boessneck, J. 1995. Final Report on the Zooarchaeological Investigation of Animal Bone Finds from Tell Hesban, Jordan. In: LaBianca, Ø.S. and von den Driesch, A. (eds.), Faunal Remains: Taphonomical and Zooarchaeological Studies of the Animal Remains from Tell Hesban and Vicinity. Hesban 13. Berrien Springs, MA: Andrews University, 65-108.

Driscoll, C.A., Macdonald, D.W., and O'Brien, S.J. 2009. From Wild Animals to Domestic Pets, an Evolutionary View of Domestication. Proceedings of the National Academy of Sciences 106:1, 9972.

Driver, G. R. 1955a. Birds in the Old Testament: I. Birds in Law. Palestine Exploration Quarterly $87,5-20$.

Driver, G. R. 1955b. Birds in the Old Testament: II. Birds in Life. Palestine Exploration Quarterly $87,129-40$.

Driver, G. R. 1958. Once Again: Birds in the Bible. Palestine Exploration Quarterly 90, 56-58.

Drori, I. and Tchernov, E. 2004. Appendix VI: An Assemblage of Bird Bones from Area P. In: Ussishkin, D. (ed.) The Renewed Archaeological Excavations at Lachish (1973-1994). (Tel Aviv University Monograph Series) Tel Aviv: Institute of Archaeology, 2453-2456. 
Eda, M., Lu, P., Kikuchi, H., Li, Z., Li, F., and Yuan, J. 2016. Reevaluation of Early Holocene Chicken Domestication in Northern China. Journal of Archaeological Science, 67, 25-31.

Eggler, J. Forthcoming. “Rooster." In: Uehlinger, C. and Eggler, J. (ed.) Iconography of Deities and Demons in the Ancient Near East. Leiden: Brill.

Ericson, P. G. 1987. Interpretations of Archaeological Bird Remains: A Taphonomic Approach. Journal of Archaeological Science, 14(1), 65-75.

Finkelstein, I., Koch, I. and Lipschits, O. 2011. The Mound on the Mount: A Possible Solution to the "Problem with Jerusalem". Journal of Hebrew Scripture, 11(12), 2-23.

Fulton, D., Gadot, Y., Kleiman, A., Freud, L., Lernau, O., and Lipschits, O. 2015. Feasting in Paradise: Feast Remains from the Iron Age Palace of Ramat Rahel and Their Implications. Bulletin of the American Schools of Oriental Research, 374, 29-8.

Geva, H. 2014. Jerusalem's Population in Antiquity: A Minimalist View 1. Tel Aviv, 41(2), 131-60.

Gilboa, A. and Sharon, I. 2003. An Archaeological Contribution to the Early Iron Age Chronological Debate: Alternative Chronologies for Phoenicia and Their Effects on the Levant, Cyprus, and Greece. Bulletin of the American Schools of Oriental Research, 332, 7-80.

Habel, N.C. 1985. The Book of Job, a Commentary, OTL Philadelphia: Westminster.

Hahn, E. 1896. Die Haustiere und ihre Beziehungen zur Wirtschaft des Menschen. Leipzig: Duncker und Humblot.

Hakker-Orion, D. 2007. The Faunal Remains. In: Cohen, R. and Bernick-Greenberg, H., (eds.) Excavations at Kadesh Barnea (Tell El-Qudeirat), 1976-1982. Jerusalem: Israel Antiquities Authority, 285-302.

Hammer, Ø., Harper, D.A. T. and Ryan, P.D. 2001. PAST: Paleontological Statistics Software Package for Education and Data Analysis. Palaeontologia Electronica 4. Retrieved from http://palaeo-electronica.org/2001_1/past/issue1_01.htm.

Harper, J. 1972. The Tardy Domestication of the Duck. Agricultural History, 46(3), 385-389.

Hellwing, S. and Feig, N. 1989. Animal Bones. In: Herzog, Z., Rapp Jr., G., and Negbi, O., (eds.) Excavation at Tel Michal, Israel. Minneapolis: University of Minnesota Press, 236-247.

Hellwing, S., Sade, M., and Kishon, V. 1993. Faunal Remains. In: Finkelstein, I., (ed.) Shiloh: The Archaeology of a Biblical Site. Monograph Series of the Institute of Archaeology Tel Aviv University 10. Tel Aviv: Institute of Archaeology of Tel Aviv University, Publications Section, 309-325.

Hendel, R. 2007. Table and Altar: The Anthropology of Food in the Priestly Torah. In: Coote, R.B. and Gottwald, N.K., (eds.) To Break Every Yoke: Essays in Honor of Marvin L. Chaney. Sheffield: Sheffield Phoenix Press, 131-148.

Hirschfeld, Y. and Tepper, Y. 2006. Columbarium Towers and Other Structures in the Environs of Shivta. Tel Aviv, 83-116.

Hole. F. 1994. Environmental Instabilities and Urban Origins. In: Stein. G., and Rothman. M.S., (eds.) Chiefdoms and Early States in the Near East: The Organizational Dynamics of Complexity (Monographs in World Prehistory 18) Madison, WI: Prehistory Press, 121-152

Horwitz, L.K. 2000. Animal Exploitation: Archaeozoological Analysis. In: Gal, Z. and Alexandre, Y., (eds.) Horvat Rosh Zayit: An Iron Age Storage Fort and Village. Jerusalem: Israel Antiquities Authority, 221-232.

Horwitz, L.K. and Tchernov, E. 1989. Subsistence Patterns in Ancient Jerusalem: A Study of Animal Remains. In: Mazar, E. and Mazar. B., (eds.) Excavations in the South of the Temple Mount (Qedem 29) Jerusalem: Hebrew University, 144-154.

Horwitz, L.K. and Tchernov, E. 1996. Bird Remains from Areas A, D, H, and K. In: Ariel, D. and De Groot, A., (eds.) Excavations at the City of David Final Report IV (Qedem 35) Jerusalem: Hebrew University, 298-301.

Horwitz, L.K., Bar Giora, N., Mienis, H.K., and Lernai, O. 2005. Faunal and Malacological Remains from the Middle Bronze, Late Bronze and Iron Age Levels at Tel Yoqne'am. In: Ben-Tor, A., Ben-Ami, D., and Livneh, A. (eds.) The Middle and Late Bronze Ages of Tel Yoqne'am: Final Report of the Archaeological Excavations (1977-1988) (Qedem 7). Jerusalem: Institute of Archaeology, 395-436.

Houlihan, P.F. 1986. The Birds of Ancient Egypt. Warminster: Aris and Phillips 
Houlihan, P.F. 2001. Birds. In: Redford, D.B., (ed.) The Oxford Encyclopedia of Ancient Egypt 1. New York, 189-191.

Houston, W. 1993. Purity and Monotheism: Clean and Unclean Animals in Biblical Law. Sheffield: Sheffield Press.

Jennings, M. C. 1986. The Distribution of the Extinct Arabian Ostrich Struthio camelus syriacus Rothschild, 1919. Fauna of Saudi Arabia, 8, 447-461.

Jones, C. 2016. Interregional Connections during the Late Bronze Age Reflected through the Animal Economy: Azekah a Case Study. Unpublished MA. Tel Aviv University.

Kakish, R. 2012. Evidence for Dove Breeding in the Iron Age: A Newly Discovered Dovecote at 'Ain al-Baida/'Amman. Jordan Journal for History and Archaeology 6, 175-93.

Karenberg, A., and Leitz, C. 2001. Headache in Magical and Medical Papyri of Ancient Egypt. Cephalalgia 21, 911-916.

Keel O., and Winter, U. 1977. Vögel als Boten: Studien zu Ps 68, 12-14, Gen 8, 6-12, Koh 10, 20 und dem Aussenden von Botenvögeln in Ägypten. OBO 14. Fribourg: Presses Universitaire.

Kersten, A. M. 1991. Birds from the Palaeolithic Rock Shelter of Ksar 'Akil, Lebanon. Paléorient, 99-116.

Kehati, R. 2009. The Faunal Assemblage. In: Garfinkel, Y., and Ganor, S., (eds.) Khirbet Qeiyafa. Vol 1. Excavation Report 2007-2008. Jerusalem: Israel Exploration Society and Institute of Archaeology, 201-208.

Koch, I. 2014. Goose Keeping, Elite Emulation and Egyptianized Feasting at Late Bronze Lachish, Tel Aviv, 41:2, 161-179

Lambert, W.G. 1970. The Sultantepe Tablets: IX. The Birdcall Text. Anatolian Studies, 20, $111-$ 117.

Langgut, D., Finkelstein, I. and Litt, T. 2013. Climate and the Late Bronze Collapse: New Evidence from the Southern Levant. Tel Aviv, 40(2), 149-175.

Lernau, H., and Lernau, O. 1989. Fish Bone Remains. In: Mazar, E. and Mazar. B., (eds). Excavations in the South of the Temple Mount. (Qedem 29). Jerusalem, 155-161.

Lev-Tov, J. 2000. Pigs, Philistines, and the Ancient Animal Economy of Ekron from the Late Bronze Age to the Iron Age II. Unpublished Ph.D. Dissertation, University of Tennessee, Knoxville.

Lev-Tov, J. 2012a. Archaeozoological Reports, A: Archaeozoological Analysis of Animal Bones from A2 and A4. In: Ben-Tor, A., Ben-Ami, D., Sandhaus, D., (eds.) Hazor VI: The 1990-2009 Excavation The Iron Age. Jerusalem: Israel Exploration Society, 586-603.

Lev-Tov, J. 2012b. A Preliminary Report on the Late Bronze and Iron Age Faunal Assemblages from Tell es-Safi/Gath. In: Maeir, A., (ed.) Tell es-Safi/Gath I: Report on the 1996-2005 Seasons. Wiesbaden: Harrassowitz, 589-612.

Lev-Tov, Elan, J.S., Porter, B.W., and Routledge, B.E. 2011. Measuring Local Diversity in Early Iron Age Animal Economies: A View from Khirbat al-Mudayna al- 'Aliya (Jordan). Bulletin of the American Schools for Oriental Research 361, 67-93.

Lev-Tov, J., and McGeough, K. 2007. Examining Feasting in Late Bronze Age Syro-Palestine through Ancient Texts and Bones. In: Twiss, K. (ed.) The Archaeology of Food and Identity (Southern Illinois University, Center for Archaeological Investigations, Occasional Paper 34) Carbondale, IL: Center for Archaeological Investigations, Southern Illinois University, 85-111.

Lichtheim, M. 1997. The Report of Wenamun. In: Hallo, W.W. and K.L. Younger (eds.) The Context of Scripture. Leiden: Brill Vol. 1.

Lipschits, O. 2011. Jerusalem between Two Periods of Greatness: The Size and Status of Jerusalem in the Babylonian, Persian and Early Hellenistic Periods. In: Lipschits, O. and Grabbe, L.L., (eds.) Judah between East and West: The Transition from Persian to Greek Rule (ca. 400-200 BCE), The Library of Second Temple Studies, T\&T Clark International, 163-175.

Lisk, E. 1999. Tel Dor: An Iron Age Port City Zooarchaeological Analysis. Unpublished M.Sc. thesis, Tel Aviv University.

Loud, G. 1939. The Megiddo Ivories (The University of Chicago Oriental Institute Publications 52). Chicago: University of Chicago.

Madge, S., and McGowan, P. 2002. Pheasants, Partridges and Grouse. London: Black.

Marom, N. 2012. Archaeozoological Reports, B: Archaeozoological Analysis of Animal Bones from 
Selected Iron Age Contexts. In: Ben-Tor, A., Ben-Ami, D., and Sandhaus, D., (eds.) Hazor VI: The 1990-2009 Excavation The Iron Age. Jerusalem: Israel Exploration Society, 604-623.

Marom, N. and Agha, N. In Press. Faunal Remains from the City of David- Area C, H.

Martin, E. 2012. Theriomorphismus im Alten Testament und im Alten Orient: Eine Einführung. In: Martin, E. and Heries, M. (eds.) Tiergestaltigkeit der Göttinnen und Götter zwischen Metapher und Symbol. Neukirchen-Vluyn: Neukirchener Verlag.

Meiberg, L. 2013. Casting a Wide Net: Notes on the Inspiration for the Fish Motif on Philistine Pottery. Tel Aviv 40 (1), 55-71.

Milgrom, J. 1991. Leviticus 1-16: A New Translation with Introduction and Commentary, New York: Doubleday.

Miron, R. 1990. Kamid el Loz 10: Das Schatzhaus im Palastbereich. Die Funde. Bonn: Habelt.

Motro, H. 2011. Archaeozoological Analysis of the Faunal Remains. In: Thareani, Y., (ed.) Tel' 'Aroer: the Iron Age II Caravan Town and the Hellenistic-Early Roman Settlement. Jerusalem: Hebrew Union College, 265-297.

Munro, N. 2001. A Prelude to Agriculture: Game Use and Occupation Intensity during the Natufian Period in the Southern Levant. Unpublished Dissertation, University of Arizona.

Nunn, J.F. 2002. Ancient Egyptian Medicine. Norman: University of Oklahoma Press.

Osten-Sacken, E. 2015. Untersuchungen zur Gefluegelwirtschaft im Alten Orient (OBO 272) Fribourg and Göttingen: Academic Press and Vandenhoeck \& Ruprecht.

Perry-Gal, L., Erlich, A., Gilboa, A., and Bar-Oz, G. 2015. Earliest Economic Exploitation of Chicken outside East Asia: Evidence from the Hellenistic Southern Levant. Proceedings of the National Academy of Sciences, 112(32), 9849-9854.

Perry-Gal, L. Erlich, A. Bouchnick, R. and Bar-Oz, G. 2017. The Jewish Chicken? Trends in Chicken and Pig Dispersal in the Hellenistic-Roman Southern Levant. Poster session presented at: $13^{\text {th }}$ Meeting of the Archaeozoology of Southwest Asia working group; June 7-10; Nicosia, Cyprus.

Peters, J., Lebrasseur, O., Deng, H., and Larson, G. 2016. Holocene Cultural History of Red Jungle Fowl (Gallus gallus) and its Domestic Descendant in East Asia. Quaternary Science Reviews, 142, 102-119.

Peters, J., Pöllath, N., and von den Driesch, A. 2002. Early and Late Bronze Age Transitional Subsistence at Tall al-'Transi. In: Herr, G., (eds.) Madaba Plains Project: The 1994 Season at Tall al-' Projec and Subsequent Studies. Berrien Springs, MI: Andrews University, 305-347.

Petrie, F. 1930. Beth-Pelet I (Tell Fara) (Publications of the Egyptian Research Account and British School of Archaeology in Egypt 48). London.

Raban-Gerstel, N. 2005. Faunal Remains from Tel Dor: An Early Iron Age Port City. MA Thesis, University of Haifa (in Hebrew).

Raban-Gerstel, N., Bar-Oz, G., Zohar, I., Sharon, I., and Gilboa, A. 2008. Early Iron Age Dor (Israel): A Faunal Perspective. Bulletin of the American Schools for Oriental Research, 349, 25-59.

Redding, R.W. 2015. The Pig and the Chicken in the Middle East: Modeling Human Subsistence Behavior in the Archaeological Record Using Historical and Animal Husbandry Data. Journal Archaeological Research, 23, 163-213.

Reich, R., Shukron, E. and Lernau, O. 2007. Recent Discoveries in the City of David, Jerusalem. Israel Exploration Journal, 153-169.

Reitz, E. and Wing, E. 2008. Zooarchaeology (Second Edition). Cambridge: Cambridge University Press.

Russell, N. 2011. Social Zooarchaeology: Humans and Animals in Prehistory. Cambridge: Cambridge University Press.

Salonen, A. 1973. Vögel und Vogelfang im alten Mesopotamien, Annales Academiae scientiarum Fennicae. Ser. B 180. Helsinki: Suomalainen Tiedeakatemia.

Sapir-Hen, L. 2015. Faunal Remains from Tel Halif. In: Borowski, O., (ed.) The Tel Halif Excavations PHASE IV. 2014 Field Season Field V. Atlanta: Emory University, 167-81.

Sapir-Hen, L., Gadot, Y. and Finkelstein, I. 2014. Environmental and Historical Impacts on Long Term Animal Economy: the Southern Levant in the Late Bronze and Iron Ages. Journal of the Economic and Social History of the Orient, 57(5), 703-744.

Sass, B. 1993. The Pre-Exilic Hebrew Seals: lconism vs. Aniconism. In: Studies in the Iconography of 
Northwest Semitic Inscribed Seals: Proceedings of a Symposium Held in Fribourg on April 17-20, 1991. OBO 125. Fribourg/Göttingen: Presses Universitaire/Vandenhoeck \& Ruprecht, 194-256.

Sasson, A. 2016. The Faunal Remains from Stratum II: Zooarchaeological, Taphonomic and GIS Spatial Analyses. In: Herzog, Z. and Singer-Avitz, L., (eds.) Beer-Sheba III, The Early Iron IIA Enclosed Settlement and the Late Iron IIA-Iron IIB Cities, Volume III. Winona Lake: Eisenbrauns, 1364-1409.

Scalf, F. 2012. The Role of Birds within the Religious Landscape of Ancient Egypt. In: BailleulLeSuer, R., (ed.) Between Heaven and Earth: Birds in Ancient Egypt. Chicago: The Oriental Institute of the University of Chicago, 33-40.

Schmid, K., 2012. The Old Testament: A Literary History. Minneapolis: Fortress.

Shapiro, M. D., and Domyan, E. T. 2013. Domestic pigeons. Current Biology, 23(8), 302-303.

Smith, E.A., 1983. Anthropological Applications of Optimal Foraging Theory: a Critical Review. Current Anthropology 24, 625-651.

Sossinka, R. 1982. Domestication in birds. In: Farner, D.S., King, A.S., and Parkes, K.C., (eds.) Avian Biology, 6., London: Academic Press, 373-403.

Spiciarich, A. and Sapir-Hen, L. 2016 (Unpublished Report). Beit Hakerem Faunal Report. Unpublished Report Submitted to Yaa'kov Billig.

Spiciarich, A., Sapir-Hen, L., and Lernau, O. Unpublished Report. Area D3 Faunal Report.

Staubli, Thomas. 2008. Hühneropfer im Alten Israel: Zu Verstandnis von Lev 1,14 im Kontext der antiken Kulturgeschichte: In: Römer, T., (ed.) The Book of Leviticus and Numbers (Bibliotheca ephemeridum theologicarum Lovaniensium 215) 2006, 355-369.

Stringham, S. A., Mulroy, E. E., Xing, J., Record, D., Guernsey, M. W., Aldenhoven, J. T., Osborne, E.J., and Shapiro, M. D. 2012. Divergence, Convergence, and the Ancestry of Feral Populations in the Domestic Rock Pigeon. Current Biology, 22(4): 302-308.

Tamar, K., and Bar-Oz, G. 2015. Zooarchaeological Analysis of the Faunal Remains. In: Mazar, E., ed. 2015. The Summit of the City of David Excavations 2005-2008. Jerusalem: 497-510.

Tamar, K., Bar-Oz, G., Bunimovitz, S., Lederman, Z. and Dayan, T. 2015. Geography and Economic Preferences as Cultural Markers in a Border Town: The Faunal Remains from Tel BethShemesh, Israel. International Journal of Osteoarchaeology, 25(4), 414-425.

Twiss, K.C. 2008. Transformations in an Early Agricultural Society: Feasting in the Southern Levantine Pre-Pottery Neolithic. Journal of Anthropological Archaeology 27, 418-442.

Twiss, K.C. 2012. The Archaeology of Food and Social Diversity. Journal of Archaeological Research, 20(4), 357-395.

Watts, J. W. 2013. Leviticus 1-10, HCOT. Leuven: Peeters, 218.

Xiang, H., Gao, J., Yu, B., Zhou, H., Cai, D., Zhang, Y., Chen, X., Wang, X., Hofreiter, M. and Zhao, X. 2014. Early Holocene Chicken Domestication in Northern China. Proceedings of the National Academy of Sciences, 111(49), 17564-17569.

Yasur-Landau, A. 2009. On the Origin of the Philistine Bird Motif. EI 29, 231-241 (Hebrew).

Yuan, J. 2010. Zooarchaeological Study on the Domestic Animals in Ancient China. Quat. Sci. 30 (2), 298-307.

Ziffer, I. 2005. From Acemhöyük to Megiddo: The Banquet Scene in the Art of the Levant in the Second Millenium BCE. Tel Aviv 32, 133-167. 


\section{Appendix I: Avian Databases}

Table 1. Iron Age I

\begin{tabular}{|c|c|c|c|c|c|}
\hline Site & Birds Present & NISP & NISP\% & Reference & Collection Method \\
\hline \multirow[t]{12}{*}{$\begin{array}{l}\text { Beth Shemesh, } \\
\text { Level 7-4 }\end{array}$} & $\begin{array}{l}\text { Vulture/Pelican } \\
\text { size }\end{array}$ & 1 & $3 \%$ & $\begin{array}{l}\text { Tamar et al. } \\
2013\end{array}$ & Hand \\
\hline & $\begin{array}{l}\text { Struthio camelus } \\
\text { syriacus }\end{array}$ & 1 & $3 \%$ & & \\
\hline & Phasianidae & 1 & $3 \%$ & & \\
\hline & Passiformes & 1 & $3 \%$ & & \\
\hline & Partridge size & 6 & $19 \%$ & & \\
\hline & $\begin{array}{l}\text { Neophron } \\
\text { percnoptrerus }\end{array}$ & 1 & $3 \%$ & & \\
\hline & Gyps fulvus & 3 & $10 \%$ & & \\
\hline & Falconidae & 1 & $3 \%$ & & \\
\hline & Corvus corone & 2 & $6 \%$ & & \\
\hline & Buteo buteo & 1 & $3 \%$ & & \\
\hline & Anatidae & 2 & $6 \%$ & & \\
\hline & Alectoris chukar & 11 & $35 \%$ & & \\
\hline $\begin{array}{l}\text { City of David, } \\
\text { Area D1 }\end{array}$ & Anser Anser & 3 & $75 \%$ & $\begin{array}{l}\text { Horwitz and } \\
\text { Tchernov } \\
1996\end{array}$ & Hand and Sieved \\
\hline Str. 15 & Alectoris chukar & 1 & $25 \%$ & & \\
\hline Hazor, Area A2 & Anser Anser & 2 & $100 \%$ & $\begin{array}{l}\text { Lev-Tov } \\
2012 \mathrm{a}\end{array}$ & Not Stated \\
\hline $\begin{array}{l}\text { Horbat Rosh } \\
\text { Zayit, } \\
\text { Str. 11B (L78) }\end{array}$ & Tyto alba & 1 & $100 \%$ & $\begin{array}{l}\text { Horwitz } \\
2000\end{array}$ & Hand \\
\hline \multirow[t]{3}{*}{$\begin{array}{l}\text { Khirbat al-Mu- } \\
\text { dayna al-'Aliya }\end{array}$} & Passiformes & 1 & $8 \%$ & $\begin{array}{l}\text { Lev-Tov et al. } \\
2011\end{array}$ & Hand \\
\hline & Aves & 10 & $83 \%$ & & \\
\hline & Ardea cinerea & 1 & $8 \%$ & & \\
\hline \multirow[t]{3}{*}{ Shiloh, Str. 5} & Gallus gallus & 5 & $71 \%$ & $\begin{array}{l}\text { Hellwing et } \\
\text { al. } 1993\end{array}$ & Hand \\
\hline & Columba livia & 1 & $14 \%$ & & \\
\hline & Anser anser & 1 & $14 \%$ & & \\
\hline \multirow[t]{2}{*}{ Tel Dor, Area D2 } & $\begin{array}{l}\text { Phalacrocorax } \\
\text { carbo }\end{array}$ & 2 & $7 \%$ & Lisk 1999 & Hand and Sieved \\
\hline & Pelican sp. & 5 & $17 \%$ & & \\
\hline
\end{tabular}




\begin{tabular}{|c|c|c|c|c|c|}
\hline Site & Birds Present & NISP & NISP\% & Reference & Collection Method \\
\hline & $\begin{array}{l}\text { Pelecanus } \\
\text { onocrotalus }\end{array}$ & 3 & $10 \%$ & & \\
\hline & $\begin{array}{l}\text { Himantopus } \\
\text { himantopus }\end{array}$ & 2 & $7 \%$ & & \\
\hline & Gyps fulvu & 1 & $3 \%$ & & \\
\hline & Grus gru & 1 & $3 \%$ & & \\
\hline & Anser sp. & 6 & $20 \%$ & & \\
\hline & Anser anser & 7 & $23 \%$ & & \\
\hline & $\begin{array}{l}\text { Anas platyrhyn- } \\
\text { chos }\end{array}$ & 2 & $7 \%$ & & \\
\hline & Alectoris chukar & 1 & $3 \%$ & & \\
\hline \multirow[t]{13}{*}{ Tel Dor, Area G } & $\begin{array}{l}\text { Pelecanus } \\
\text { onocrotalus }\end{array}$ & 1 & $1 \%$ & Lisk 1999 & Hand and Sieved \\
\hline & Passiformes & 8 & $9 \%$ & & \\
\hline & Laridae & 5 & $6 \%$ & & \\
\hline & Hirundinidae & 4 & $5 \%$ & & \\
\hline & Gallus & 9 & $11 \%$ & & \\
\hline & Fulica atra & 1 & $1 \%$ & & \\
\hline & Falconiformes & 1 & $1 \%$ & & \\
\hline & Ciconia ciconia & 5 & $6 \%$ & & \\
\hline & Chararidriidae & 4 & $5 \%$ & & \\
\hline & Ardeola ibis & 2 & $2 \%$ & & \\
\hline & $\begin{array}{l}\text { Anas platyrhyn- } \\
\text { chos }\end{array}$ & 19 & $22 \%$ & & \\
\hline & Alopochen sp. & 10 & $12 \%$ & & \\
\hline & Alectoris chukar & 16 & $19 \%$ & & \\
\hline \multirow[t]{3}{*}{$\begin{array}{l}\text { Tel Hesban, } \\
\text { H76C }\end{array}$} & Otis tarda & 1 & $33 \%$ & $\begin{array}{l}\text { Boessneck } \\
1995\end{array}$ & Hand \\
\hline & Fulica atra & 1 & $33 \%$ & & \\
\hline & Crex crex & 1 & $33 \%$ & & \\
\hline \multirow[t]{3}{*}{$\begin{array}{l}\text { Tel Miqne-Ekron, } \\
\text { Str. 5-7 }\end{array}$} & Phasianidae & 5 & $71 \%$ & $\begin{array}{l}\text { Lev-Tov } \\
2000\end{array}$ & Hand \\
\hline & Passiformes & 1 & $14 \%$ & & \\
\hline & Anser anser & 1 & $14 \%$ & & \\
\hline $\begin{array}{l}\text { Tel Yoqne'am, } \\
\text { Area A and B2, } \\
\text { str. } 28-27\end{array}$ & Passiformes & 2 & $11 \%$ & $\begin{array}{l}\text { Horwitz et al. } \\
2005\end{array}$ & Hand \\
\hline
\end{tabular}




\begin{tabular}{llcccr}
\hline Site & Birds Present & NISP & NISP\% & Reference & Collection Method \\
\hline & Grus grus & 8 & $44 \%$ & \\
Anas s. & 7 & $39 \%$ & \\
& Alectoris chukar & 1 & $6 \%$ &
\end{tabular}

Table 2. Iron Age II Database

\begin{tabular}{|c|c|c|c|c|c|}
\hline Site & Birds Present & NISP & NISP\% & Reference & Collection Method \\
\hline \multirow[t]{4}{*}{$\begin{array}{l}\text { Hazor, Area A2 } \\
\text { and A4 }\end{array}$} & Anser Anser & 7 & $64 \%$ & $\begin{array}{l}\text { Lev Tov } \\
2012 \mathrm{a}\end{array}$ & Not Stated \\
\hline & Phasianidae & 1 & $9 \%$ & & \\
\hline & Gallus gallus & 2 & $18 \%$ & & \\
\hline & Anas sp. & 1 & $9 \%$ & & \\
\hline \multirow[t]{2}{*}{$\begin{array}{l}\text { Tel Hesban, } \\
\text { H73B.1, H76F.38 }\end{array}$} & $\begin{array}{l}\text { Neophron } \\
\text { percnoptrerus }\end{array}$ & 1 & $25 \%$ & $\begin{array}{l}\text { Boessneck } \\
1995\end{array}$ & Hand \\
\hline & $\begin{array}{l}\text { Athene noctua } \\
\text { lilith }\end{array}$ & 3 & $75 \%$ & & \\
\hline $\begin{array}{l}\text { City of David, } \\
\text { Stepped Stone } \\
\text { Structure, }\end{array}$ & Gallus gallus & 1 & $2 \%$ & $\begin{array}{l}\text { Tamar and } \\
\text { Bar-Oz } 2015\end{array}$ & $\begin{array}{l}\text { Hand and Wet } \\
\text { Sieved }\end{array}$ \\
\hline \multirow{4}{*}{$\begin{array}{l}\text { Area G, Str. 9/10 } \\
\text { (layer 1-3) }\end{array}$} & Columba livia & 1 & $2 \%$ & & \\
\hline & Anser anser & 2 & $4 \%$ & & \\
\hline & Alectoris chukar & 18 & $37 \%$ & & \\
\hline & Aves unidentified & 27 & $55 \%$ & & \\
\hline $\begin{array}{l}\text { City of David, } \\
\text { Stepped Stone } \\
\text { Structure, }\end{array}$ & Columba livia & 12 & $14 \%$ & $\begin{array}{l}\text { Tamar and } \\
\text { Bar-Oz } 2015\end{array}$ & $\begin{array}{l}\text { Hand and Wet } \\
\text { Sieved }\end{array}$ \\
\hline \multirow[t]{3}{*}{ Area G, Str. 10} & Anser anser & 3 & $3 \%$ & & \\
\hline & Alectoris chukar & 20 & $23 \%$ & & \\
\hline & Aves unidentified & 52 & $60 \%$ & & \\
\hline \multirow[t]{3}{*}{$\begin{array}{l}\text { City of David, } \\
\text { Area D3 }\end{array}$} & Gallus gallus & 4 & $50 \%$ & $\begin{array}{l}\text { Spiciarich et } \\
\text { al. unpub- } \\
\text { lished report }\end{array}$ & Hand and Sieved \\
\hline & Columba livia & 2 & $25 \%$ & & \\
\hline & Alectoris chukar & 2 & $25 \%$ & & \\
\hline $\begin{array}{l}\text { City of David, } \\
\text { Area's D1, D2, } \\
\text { str. } 12-14\end{array}$ & Gallus gallus & 1 & $10 \%$ & $\begin{array}{l}\text { Horwitz and } \\
\text { Tchernov } \\
1996\end{array}$ & Hand \\
\hline
\end{tabular}




\begin{tabular}{|c|c|c|c|c|c|}
\hline Site & Birds Present & NISP & NISP\% & Reference & Collection Method \\
\hline & Anser anser & 4 & $40 \%$ & & \\
\hline & Alectoris chukar & 5 & $50 \%$ & & \\
\hline \multirow[t]{6}{*}{$\begin{array}{l}\text { City of David, } \\
\text { Ophel }\end{array}$} & Streptopelia sp. & 2 & $6 \%$ & $\begin{array}{l}\text { Horwitz and } \\
\text { Tchernov } \\
1989\end{array}$ & Hand \\
\hline & Gallus gallus & 6 & $17 \%$ & & \\
\hline & Columba livia & 9 & $26 \%$ & & \\
\hline & Anser anser & 8 & $23 \%$ & & \\
\hline & Alectoris chukar & 9 & $26 \%$ & & \\
\hline & Passiformes & 1 & $3 \%$ & & \\
\hline $\begin{array}{l}\text { City of David, } \\
\text { Ophel }\end{array}$ & Gallus gallus & 4 & $6 \%$ & $\begin{array}{l}\text { Spiciarich et } \\
\text { al. forthcom- } \\
\text { ing }\end{array}$ & Hand and Sieved \\
\hline \multirow{3}{*}{$\begin{array}{l}\text { Area A and } \\
\text { Area B }\end{array}$} & Anser anser & 34 & $55 \%$ & & \\
\hline & Columba livia & 2 & $3 \%$ & & \\
\hline & Alectoris chukar & 22 & $35 \%$ & & \\
\hline $\begin{array}{l}\text { City of David, } \\
\text { Giv'ati Area M1, } \\
\text { Str. } 12-9\end{array}$ & Gallus gallus & 2 & $100 \%$ & $\begin{array}{l}\text { Bar-Oz and } \\
\text { Raban-Gers- } \\
\text { tel } 2013\end{array}$ & Hand \\
\hline Beit Hakerem & Gallus gallus & 3 & $100 \%$ & $\begin{array}{l}\text { Spiciarich } \\
\text { and Sapir- } \\
\text { Hen } 2016\end{array}$ & Hand \\
\hline \multirow[t]{2}{*}{$\begin{array}{l}\text { Tel Miqne-Ekron, } \\
\text { 1c/1b, str.2-3 }\end{array}$} & Phasianidae & 6 & $67 \%$ & $\begin{array}{l}\text { Lev-Tov } \\
2000\end{array}$ & Hand \\
\hline & Passiformes & 3 & $33 \%$ & & \\
\hline Kh. Qeiyafa & Galliformes & 11 & $100 \%$ & Kehati 2009 & Hand and Sieved \\
\hline \multirow[t]{8}{*}{ Tel Dor } & $\begin{array}{l}\text { Phalacrocorax } \\
\text { carbo }\end{array}$ & 2 & $4 \%$ & $\begin{array}{l}\text { Raban-Gers- } \\
\text { tel et al. } 2008\end{array}$ & Hand and Sieved \\
\hline & $\begin{array}{l}\text { Pelecanus } \\
\text { onocrotalus }\end{array}$ & 8 & $16 \%$ & & \\
\hline & $\begin{array}{l}\text { Himantopus } \\
\text { himantopus }\end{array}$ & 2 & $4 \%$ & & \\
\hline & Gyps fulvus & 1 & $2 \%$ & & \\
\hline & Grus grus & 1 & $2 \%$ & & \\
\hline & Anser anser & 29 & $58 \%$ & & \\
\hline & $\begin{array}{l}\text { Anas platyrhyn- } \\
\text { chos }\end{array}$ & 6 & $12 \%$ & & \\
\hline & Alectoris chukar & 1 & $2 \%$ & & \\
\hline
\end{tabular}




\begin{tabular}{|c|c|c|c|c|c|}
\hline Site & Birds Present & NISP & NISP\% & Reference & Collection Metho \\
\hline Lachish, & Alectoris Chukar & 2 & $6 \%$ & Croft 2004 & $\begin{array}{l}\text { Hand and Wet } \\
\text { Sieved }\end{array}$ \\
\hline \multirow{8}{*}{$\begin{array}{l}\text { Area S, GE, } \\
\text { GW, R. Pal., } \\
\text { Levels 5-2 }\end{array}$} & Gallus gallus & 4 & $13 \%$ & & \\
\hline & Circus aerinosus & 1 & $3 \%$ & & \\
\hline & Columba livia & 3 & $9 \%$ & & \\
\hline & Fulica atra & 2 & $6 \%$ & & \\
\hline & Galeruda cristata & 1 & $3 \%$ & & \\
\hline & $\begin{array}{l}\text { Galilina } \\
\text { chloropus }\end{array}$ & 1 & $3 \%$ & & \\
\hline & Anser anser & 16 & $50 \%$ & & \\
\hline & Raven & 2 & $6 \%$ & & \\
\hline \multirow[t]{5}{*}{$\begin{array}{l}\text { Tel Yoqne'am, } \\
\text { str. } 15\end{array}$} & Columba livia & 1 & $20 \%$ & $\begin{array}{l}\text { Horwitz et al. } \\
2005\end{array}$ & Not Stated \\
\hline & Anser anser & 1 & $20 \%$ & & \\
\hline & Gallus gallus & 1 & $20 \%$ & & \\
\hline & Alectoris chukar & 1 & $20 \%$ & & \\
\hline & Anas p. & 1 & $20 \%$ & & \\
\hline $\begin{array}{l}\text { Tel Yoqne’am, } \\
\text { str. } 26\end{array}$ & Alectoris chukar & 3 & $100 \%$ & $\begin{array}{l}\text { Horwitz et al. } \\
2005\end{array}$ & Not Stated \\
\hline Bab-el-Hawa & Gallus gallus & 12 & $100 \%$ & $\begin{array}{l}\text { Raphael and } \\
\text { Lernau } 1996\end{array}$ & Hand \\
\hline \multirow[t]{3}{*}{$\begin{array}{l}\text { Ramat Rahel, } \\
\text { L.14109 }\end{array}$} & Phasianidae & 39 & $91 \%$ & $\begin{array}{l}\text { Fulton et al. } \\
2015\end{array}$ & Hand and Sieved \\
\hline & Columba livia & 3 & $7 \%$ & & \\
\hline & Anser anser & 1 & $2 \%$ & & \\
\hline
\end{tabular}

Table 3. Persian Database

\begin{tabular}{llccll}
\hline Site & Birds Present & NISP & NISP\% & Reference & Collection Method \\
\hline $\begin{array}{l}\text { City of David, } \\
\text { Area G }\end{array}$ & Alectoris chukar & 6 & $11 \%$ & Tamar and \\
str. 9A-B & & & & Bar-Oz 2015 & \\
& Anser anser & 1 & $2 \%$ & \\
& Columba livia & 5 & $9 \%$ & \\
& Falconidae & 1 & $2 \%$ & \\
& Gallus gallus & 1 & $2 \%$ &
\end{tabular}




\begin{tabular}{|c|c|c|c|c|c|}
\hline Site & Birds Present & NISP & NISP\% & Reference & Collection Method \\
\hline $\begin{array}{l}\text { Horvat Zimri, } \\
\text { L. } 5110 \text {. L.5114, } \\
\text { L.5128 }\end{array}$ & Gallus gallus & 2 & $100 \%$ & $\begin{array}{l}\text { Horwitz } \\
1993\end{array}$ & \\
\hline Tel 'Ira & Gallus gallus & 3 & $100 \%$ & Dayan 1999 & \\
\hline \multirow[t]{3}{*}{ Tel Michal } & Anser anser & 12 & $13 \%$ & $\begin{array}{l}\text { Hellwing } \\
\text { and Feig } \\
1989\end{array}$ & \\
\hline & Gallus gallus & 51 & $54 \%$ & & \\
\hline & $\begin{array}{l}\text { Struthio camelus } \\
\text { syriacus }\end{array}$ & 32 & $34 \%$ & & \\
\hline
\end{tabular}

Table 4. Hellenistic Database

\begin{tabular}{|c|c|c|c|c|c|}
\hline Site & Birds Present & NISP & NISP\% & Reference & Collection Method \\
\hline $\begin{array}{l}\text { City of David, } \\
\text { Giv'ati Area M1, } \\
\text { str. } 8\end{array}$ & Gallus gallus & 127 & $100 \%$ & $\begin{array}{l}\text { Bar-Oz and } \\
\text { Raban-Gers- } \\
\text { tel } 2013\end{array}$ & \\
\hline \multirow[t]{3}{*}{$\begin{array}{l}\text { City of David, } \\
\text { Area D2, } \\
\text { str.7A_B }\end{array}$} & Anser anser & 1 & $14 \%$ & $\begin{array}{l}\text { Horwitz and } \\
\text { Tchernov } \\
1996\end{array}$ & \\
\hline & Columba livia & 4 & $57 \%$ & & \\
\hline & Gallus gallus & 2 & $29 \%$ & & \\
\hline $\begin{array}{l}\text { City of David, } \\
\text { Area D3 }\end{array}$ & Gallus gallus & 2 & $100 \%$ & $\begin{array}{l}\text { Spiciarich et } \\
\text { al. unpub- } \\
\text { lished report }\end{array}$ & \\
\hline Kh. Qeiyafa & $\begin{array}{l}\text { Galliformes, } \\
\text { Chukar }\end{array}$ & 1 & $100 \%$ & Kehati 2009 & \\
\hline $\begin{array}{l}\text { Sha'ar-Ha'am- } \\
\text { akim }\end{array}$ & Gallus gallus & 35 & $100 \%$ & Bar-Oz 2008 & \\
\hline \multirow[t]{2}{*}{ Tel Michal } & Gallus gallus & 19 & $73 \%$ & $\begin{array}{l}\text { Hellwing } \\
\text { and Feig } \\
1989\end{array}$ & \\
\hline & $\begin{array}{l}\text { Struthio camelus } \\
\text { syriacus }\end{array}$ & 7 & $27 \%$ & & \\
\hline Maresha & Gallus gallus & 1092 & $100 \%$ & $\begin{array}{l}\text { Perry-Gal et } \\
\text { al. } 2015\end{array}$ & \\
\hline Horvat Mesad & Gallus gallus & 13 & $100 \%$ & Sade 2012 & Hand \\
\hline Horvat Uza & Gallus gallus & 62 & $100 \%$ & Sade 2007 & Hand \\
\hline
\end{tabular}


Table 5. Jerusalem Database

\begin{tabular}{|c|c|c|c|c|c|}
\hline Area & Period & Bird & NISP & NISP\% & Reference \\
\hline \multirow[t]{2}{*}{$\begin{array}{l}\text { City of David, } \\
\text { str. } 15\end{array}$} & Iron I & Anser anser & 3 & $75 \%$ & $\begin{array}{l}\text { Horwitz and } \\
\text { Tchernov } \\
1996\end{array}$ \\
\hline & & Alectoris chukar & 1 & $25 \%$ & \\
\hline \multirow[t]{6}{*}{$\begin{array}{l}\text { City of David, } \\
\text { Ophel }\end{array}$} & Iron IIA & Streptopelia sp. & 2 & $6 \%$ & $\begin{array}{l}\text { Horwitz and } \\
\text { Tchernov } \\
1989\end{array}$ \\
\hline & & Gallus gallus & 6 & $17 \%$ & \\
\hline & & Columba livia & 9 & $26 \%$ & \\
\hline & & Anser anser & 8 & $23 \%$ & \\
\hline & & Alectoris chukar & 9 & $26 \%$ & \\
\hline & & Passiformes & 1 & $3 \%$ & \\
\hline \multirow[t]{3}{*}{$\begin{array}{l}\text { City of David, } \\
\text { Area D3 }\end{array}$} & Iron IIB & Gallus gallus & 4 & $50 \%$ & $\begin{array}{l}\text { Spiciarich et } \\
\text { al. unpub- } \\
\text { lished report }\end{array}$ \\
\hline & & Columba livia & 2 & $25 \%$ & \\
\hline & & Alectoris chukar & 2 & $25 \%$ & \\
\hline \multirow[t]{3}{*}{$\begin{array}{l}\text { City of David, } \\
\text { Area's D1, D2, } \\
\text { str. } 12-14\end{array}$} & Iron IIB & Gallus gallus & 1 & $10 \%$ & $\begin{array}{l}\text { Horwitz and } \\
\text { Tchernov } \\
1996\end{array}$ \\
\hline & & Anser anser & 4 & $40 \%$ & \\
\hline & & Alectoris chukar & 5 & $50 \%$ & \\
\hline $\begin{array}{l}\text { City of David, } \\
\text { Giv'ati Area M1, } \\
\text { Str. } 12-9\end{array}$ & Iron II & Gallus gallus & 2 & $100 \%$ & $\begin{array}{l}\text { Bar-Oz and } \\
\text { Raban-Gers- } \\
\text { tel } 2013\end{array}$ \\
\hline $\begin{array}{l}\text { City of David, } \\
\text { Area G, str. } 10\end{array}$ & Iron IIB & Columba livia & 12 & $14 \%$ & $\begin{array}{l}\text { Tamar and } \\
\text { Bar-Oz } 2015\end{array}$ \\
\hline \multirow{3}{*}{$\begin{array}{l}\text { Stepped Stone } \\
\text { Structure }\end{array}$} & & Anser anser & 3 & $3 \%$ & \\
\hline & & Alectoris chukar & 20 & $23 \%$ & \\
\hline & & Aves unidentified & 52 & $60 \%$ & \\
\hline \multirow[t]{5}{*}{$\begin{array}{l}\text { City of David, } \\
\text { Area G }\end{array}$} & $\begin{array}{l}\text { Iron IIC (Baby- } \\
\text { lonian) }\end{array}$ & Gallus gallus & 1 & $2 \%$ & $\begin{array}{l}\text { Tamar and } \\
\text { Bar-Oz } 2015\end{array}$ \\
\hline & & Columba livia & 1 & $2 \%$ & \\
\hline & & Anser anser & 2 & $4 \%$ & \\
\hline & & Alectoris chukar & 18 & $37 \%$ & \\
\hline & & Aves unidentified & 27 & $55 \%$ & \\
\hline
\end{tabular}




\begin{tabular}{|c|c|c|c|c|c|}
\hline Area & Period & Bird & NISP & NISP\% & Reference \\
\hline \multirow[t]{5}{*}{$\begin{array}{l}\text { City of David, } \\
\text { Area G }\end{array}$} & Persian & Alectoris chukar & 6 & $43 \%$ & $\begin{array}{l}\text { Tamar and } \\
\text { Bar-Oz } 2015\end{array}$ \\
\hline & & Anser anser & 1 & $7 \%$ & \\
\hline & & Columba livia & 5 & $36 \%$ & \\
\hline & & Falconidae & 1 & $7 \%$ & \\
\hline & & Gallus gallus & 1 & $7 \%$ & \\
\hline \multirow[t]{3}{*}{$\begin{array}{l}\text { City of David, } \\
\text { Area D2 }\end{array}$} & Hellenistic & Anser anser & 1 & $14 \%$ & $\begin{array}{l}\text { Horwitz and } \\
\text { Tchernov } \\
1996\end{array}$ \\
\hline & & Columba livia & 4 & $57 \%$ & \\
\hline & & Gallus gallus & 2 & $29 \%$ & \\
\hline $\begin{array}{l}\text { City of David, } \\
\text { Area D3 }\end{array}$ & Hellenistic & Gallus gallus & 2 & $100 \%$ & $\begin{array}{l}\text { Spiciarich et } \\
\text { al. unpub- } \\
\text { lished report }\end{array}$ \\
\hline $\begin{array}{l}\text { City of David, } \\
\text { Giv'ati Area M1, } \\
\text { Str. 8-7 }\end{array}$ & Hellenistic & Gallus gallus & 152 & $100 \%$ & $\begin{array}{l}\text { Bar-Oz and } \\
\text { Raban-Gers- } \\
\text { tel } 2013\end{array}$ \\
\hline $\begin{array}{l}\text { City of David, } \\
\text { Area's C and L }\end{array}$ & Early Roman & Alectoris chukar & 10 & $2 \%$ & $\begin{array}{l}\text { Bar-Oz et al. } \\
\text { 2007; Bouch- } \\
\text { nick } 2011\end{array}$ \\
\hline \multirow{4}{*}{$\begin{array}{l}\text { Northern Land- } \\
\text { fill }\end{array}$} & & Anser anser & 2 & $0 \%$ & \\
\hline & & Columba livia & 111 & $23 \%$ & \\
\hline & & Gallus gallus & 319 & $65 \%$ & \\
\hline & & Passiformes & 47 & $10 \%$ & \\
\hline $\begin{array}{l}\text { City of David, } \\
\text { Area D3 }\end{array}$ & Early Roman & Alectoris chukar & 7 & $2 \%$ & $\begin{array}{l}\text { Spiciarich et } \\
\text { al. } 2017\end{array}$ \\
\hline \multirow{3}{*}{$\begin{array}{l}\text { Southern Land- } \\
\text { fill }\end{array}$} & & Anas platyrhynchos & 3 & $1 \%$ & \\
\hline & & Anser anser & 1 & $0 \%$ & \\
\hline & & Gallus gallus & 393 & $97 \%$ & \\
\hline Mt. Zion Dump & Early Roman & Gallus gallus & 7 & $100 \%$ & $\begin{array}{l}\text { Bouchnick } \\
2011\end{array}$ \\
\hline \multirow[t]{3}{*}{$\begin{array}{l}\text { City of David, } \\
\text { Area A1 and H - } \\
\text { str. } 6\end{array}$} & Early Roman & Anas platyrhynchos & 2 & $4 \%$ & $\begin{array}{l}\text { Horwitz and } \\
\text { Tchernov } \\
1996\end{array}$ \\
\hline & & Anser anser & 28 & $58 \%$ & \\
\hline & & Gallus gallus & 18 & $38 \%$ & \\
\hline $\begin{array}{l}\text { Western Wall } \\
\text { Foundation }\end{array}$ & Early Roman & Gallus gallus & 86 & $100 \%$ & $\begin{array}{l}\text { Marom In } \\
\text { Press }\end{array}$ \\
\hline
\end{tabular}




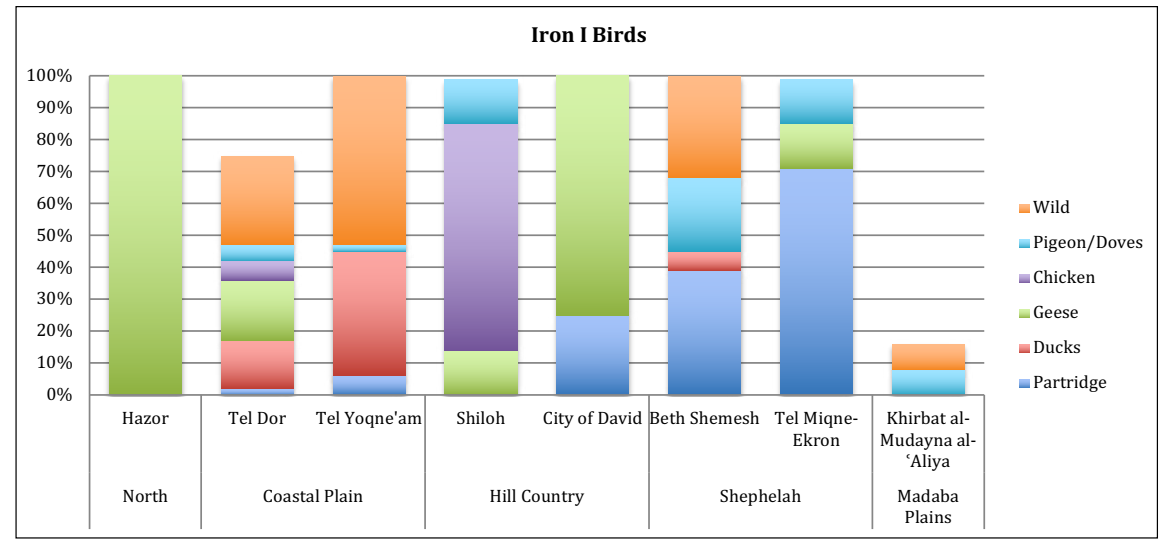

Figure 1. Bird Frequencies in the Iron Age I

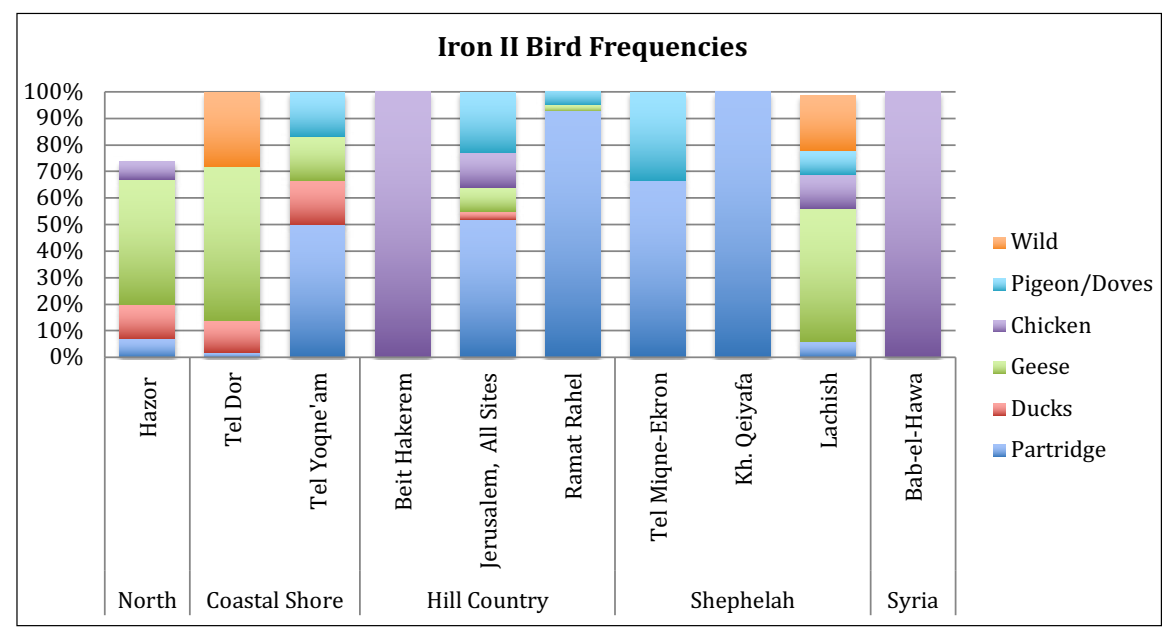

Figure 2. Bird Frequencies in the Iron Age II 


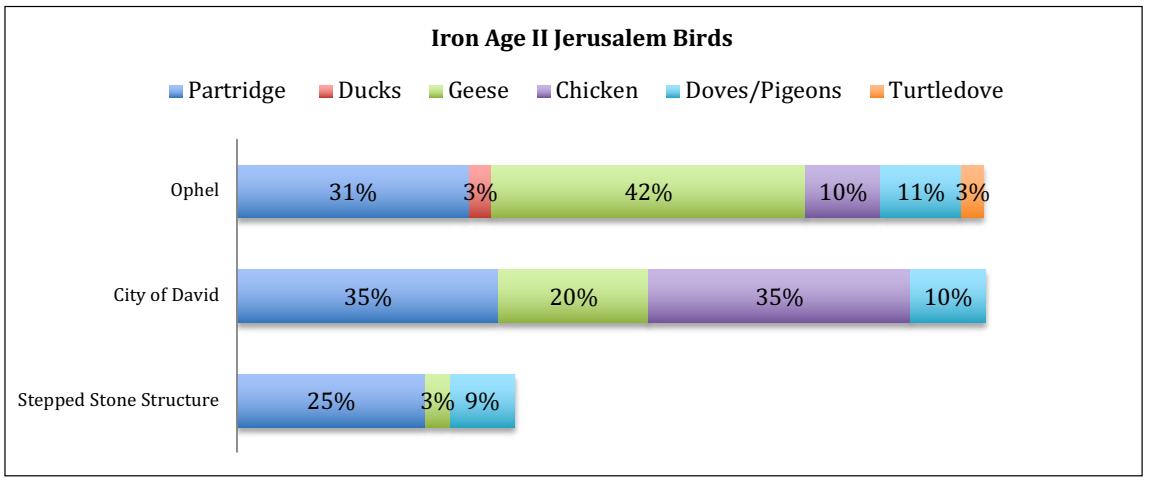

Figure 3. Bird Frequencies in Iron Age II Jerusalem

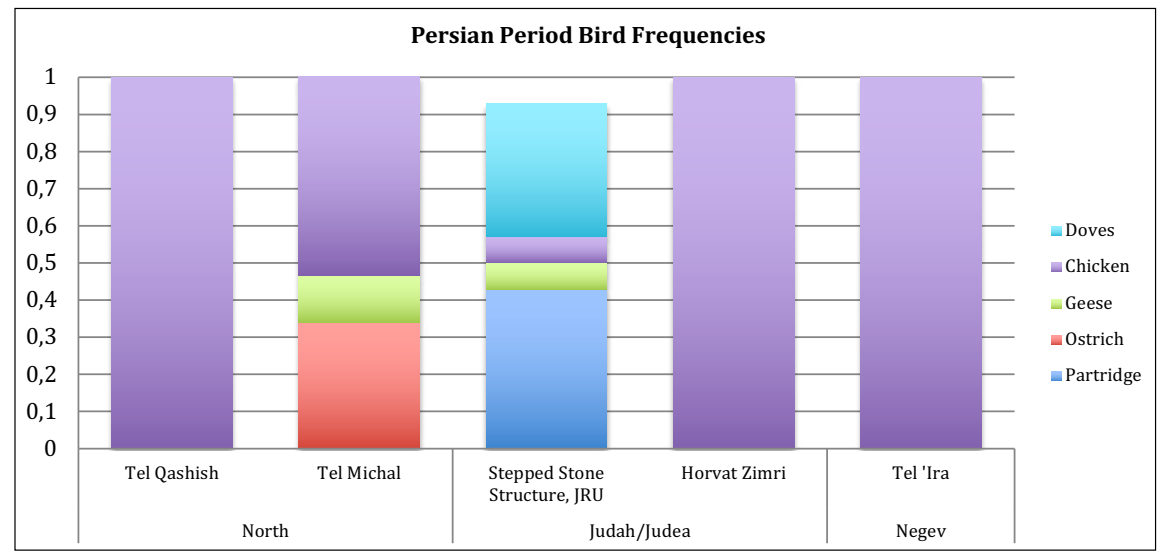

Figure 4. Bird Frequencies in the Persian Period 


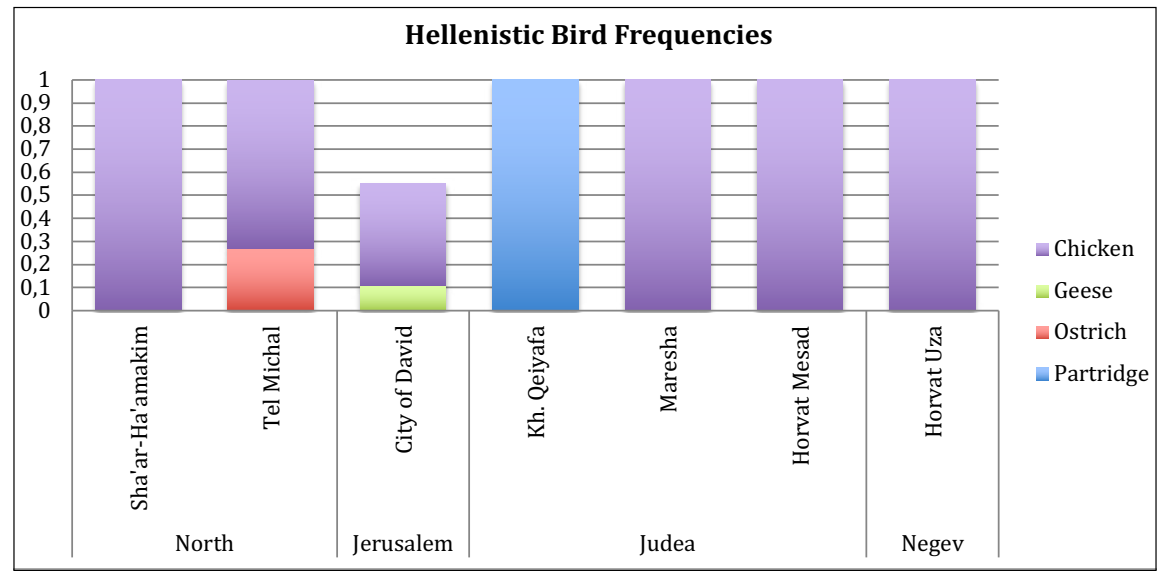

Figure 5. Bird Frequencies in the Hellenistic Period

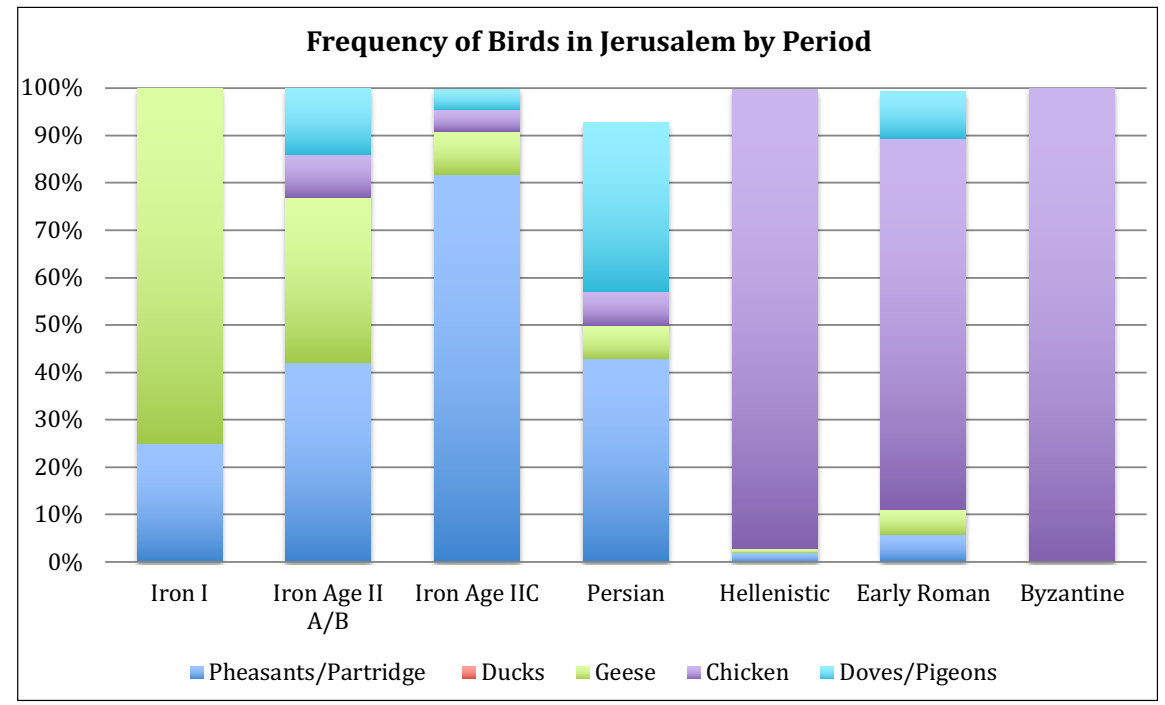

Figure 6. Bird Frequencies of Jerusalem by Period 